$5-28-2021$

\title{
Arts \& Literature: The Many Faces of Hope
}

Fiza Lee-Winter

Ruhr-Universität Bochum

Follow this and additional works at: https://digitalcommons.usf.edu/gsp

\section{Recommended Citation}

Lee-Winter, Fiza (2021) "Arts \& Literature: The Many Faces of Hope," Genocide Studies and Prevention: An International Journal: Vol. 15: Iss. 1: 5-12.

DOI:

https://doi.org/10.5038/1911-9933.15.1.1828

Available at: https://digitalcommons.usf.edu/gsp/vol15/iss1/4

This Arts \& Literature is brought to you for free and open access by the Open Access Journals at Digital Commons @ University of South Florida. It has been accepted for inclusion in Genocide Studies and Prevention: An International Journal by an authorized editor of Digital Commons @ University of South Florida. For more information, please contact digitalcommons@usf.edu. 


\section{Arts \& Literature: The Many Faces of Hope}

\section{Acknowledgements}

The author would like to acknowledge Roseline Mugaruka and Idriss Siyat for sharing their personal stories in great detail, as well as assisting with character and place development. The author would also like to acknowledge Collin Cannon for his extensive editorial contributions and for conceptually codeveloping this piece, confirming that hope is necessary to be held on to, especially in the most trying of times. 


\title{
Arts \& Literature: The Many Faces of Hope
}

\author{
Fiza Lee-Winter \\ Institut für Entwicklungsforschung \& Entwicklungspolitik (IEE) \\ Ruhr-Universität Bochum \\ Bochum, Germany
}

\begin{abstract}
About the Art Work
This essay follows the central theme- hope-a term and emotion which is arguably a coping mechanism against all hardship and suffering. It is most apparent in stories belonging to the many voices who have managed to find new lives in a third-country.
\end{abstract}

This piece is the result of a combination of formal and informal interviews conducted with refugees, field notes, conversations-individually and in group settings-and consolidated personal stories from refugees who have undergone the US resettlement program. This essay has been written with the aim of inspiring others-giving hope, in its many faces.

Characters created here are inspired by real-life persons who have had very different experiences in their journey towards resettlement-and yet, bound by the central theme, hope, which manifests itself in different ways. In the first narrative, a young boy stays behind in Kenya while his mother resettles to the United States. He longs for his mother's care, but that care is many years separated between when he can rejoin her. In the second one, a man emphasizes hope for his children. He consistently stresses his thankfulness for his family's survival, and the key to a better future now lies in the future generation. And finally, the last narrative in the collection underscores the difficulty, and resilience, in finding hope during prolonged displacement spanning across three continents.

\section{Acknowledgements}

The author would like to acknowledge Roseline Mugaruka (Home Away from Home) and Idriss Siyat (From Garissa to Greeley) for sharing their personal stories in great detail, as well as assisting with character and place development. The author would also like to acknowledge Collin Cannon, especially for his extensive editorial contributions and for conceptually codeveloping this piece, confirming that hope is necessary to be held on to, especially in the most trying of times.

\section{About the Author}

Fiza Lee-Winter is a PhD Candidate at the Institute of Development Research and Development Policy (IEE) at the Ruhr-Universität Bochum (RUB) in Germany where she is conducting her research project on the compatibilities of a human rights based approach (HRBA) to refugee protection with Asian regionalism, using the Rohingya Refugee Crisis as a case study. Her research interests include international human rights law, transnational governance, refugee and forced migration studies. She is also a member of the Institute for International Law of Peace \& Armed Conflict (IFHV) at the RUB, and an associate member of the SYLFF-Mikrokolleg on Forced Migration. Fiza has obtained her Master of Arts in Human Rights \& Democratization from EIUC/Global Campus of Human Rights and RUB, and a Bachelor of Arts in Criminal Justice from the University of Northern Colorado. Her project is fully funded and supported by the Konrad-Adenauer-Stiftung in Germany since 2019. 


\section{The Many Faces of Hope: \\ From Garissa to Greeley}

As a child, I grew up for many years away from my mother. Her distance pained me. It pained the whole family, including herself most of all. It had always been my hope to reunite with my mother and at last feel like a kid again in her arms. Life had separated us. She had flown to a foreign soil eight thousand miles away from Kenya, to the United States-a place I had only ever heard about before. But her journey to America was a dream that came to reality and a light to our family's darkness.

I was born and raised in Garissa, Kenya, a small, semi-arid town in the east of my country toward the Somali border. Dadaab, the world's largest refugee camp, was only sixty-seven miles from us, and Nairobi, the capital city, farther still at 228 miles away. Al-Shabaab, forming a few years prior in Somalia, was just beginning to be seen for the threat that it posed during my childhood.

Life in Garissa was tough. My father worked as a middleman in the livestock market, trying to convince buyers to buy the animals there and only earning himself a meager daily wage hardly enough to keep the family together. As a man, society, religion, and culture pressured him to provide for his family by any means necessary. He lived by that commitment. He never wanted to let himself down and he worked around the clock to make ends meet and to provide for us. My mother too, worked. She was a vegetable vendor in the local market-a market that's famously known as "Suuq-mugdi" which literally means the "black market." This was all that was available to her. This too earned her what would not be above basic consumption. But this was life: they both strived hard in the midst of abject poverty to make ends meet. They did this for their children, like any parents would.

My siblings and I were educated in private schools where we hardly ever attended due to a constant lack of fees. I remember spending days in a row at home for not having enough school dues or basic supplies. We switched to public schools eventually, due to financial hardship. My parents wanted the best for us and they worked for it, but that life was out of reach. Life was hitting them hard and unforgivingly; they could not keep their heads above water.

One day, there was a breakthrough: my mother had been chosen for resettlement to the United States. It was 2006, I was eight years old, and I found out that my mother would be leaving to a distant land. Alone. Without the rest of us. I vividly recall that chilly morning when my dad called in the Islamic school we were attending (what is known as Dugsi in my native language and what people from other cultures call a Madrasa) to excuse us in order to bid farewell to our mother. Farewell? My siblings and I had no context for what resettlement meant. To us, all that it meant was that our mother was leaving abruptly. Here one day, gone the next. My siblings and I walked home from the Dugsi only to find my mom fully dressed with two suitcases next to her. Our neighbors had gathered under the shade of the big tree by our house.

Seeing her ready to leave, I was confused. I was worried. Had a fight erupted between my parents? Was my mom leaving us? Where did this come from? It was not until she was leaving that someone explained to me what was happening: she was leaving for the United States. To America, that distant land from the stories and the news reports.

My worries melted. My anxiety about her leaving became anticipation of when I would get to be next. My mom and I exchanged hugs and final kisses, wiping away each other's tears. She whispered into my ear, "Don't cry, my son. I will bring the family from grass to grace and I promise that you will no longer do your homework with a torch. God willing, you will not be living much longer in a house that leaks when it rains." She stepped back and said to the family, 
"I will work for this family and keep food on this table. I promise to visit you regularly." I managed a smile on my face and gave her a tight hug once again. I did not know when that next visit would be, but I believed in this new hope. I felt that change had come.

The first night my mother was gone from home felt different. My dad had taken her to Nairobi where she would depart for the United States. My grandmother looked after us that night.

My mother started a fresh life in the United States as a refugee. She made a living and contributed to her community, becoming another stitch in the broader fabric of American lifelike so many refugees before her, bringing her own unique history and culture to this distant melting pot. She was still a mother of five and the wife to a husband, but they were eight thousand miles away. She worked in their name. She worked for their future. It paid off.

After a few years of working, my mother managed to build a two-room house for the family. My mother flew back to Kenya in 2010, four long years after she had left, to see the home she hoped to come back to one day. She came back to Kenya again in 2013, this time promising to begin the petitioning process to bring us all to the United States for good.

A lot had changed for the family in the period between when my mother left and when we could finally join her. Al-Shabaab had taken Mogadishu. The United Nations had assembled a peacekeeping force to retake Somalia. The United States' War on Terror began targeting AlShabaab in our region. Seventy-four had been killed in Kampala. Kenya had invaded Southern Somalia to secure Kismayo. Seventy-seven are killed in a Nairobi mall. Finally, one hundred and forty eight were killed and seven hundred held hostage in a fifteen-hour siege in our very town of Garissa, at the local university, in an attack by Al-Shabaab. I still remember that day. I still remember the sounds of the gunshots during the morning prayer.

But my mother's work had paid off: it was our turn to come to the United States. It was our turn to wind through the immigration bureaucracy and hope to be reunited. It was time to be together again: to be in my mother's arms as the little boy I was when she had left me. July 23, 2017 is the day I flew to America, and that day will remain in my mind like a printed paper. That date is etched into my identity now.

My family was received by my mother and her friends in Denver, Colorado. We loaded our belongings into a car and drove to Greeley, our new home, eight thousand miles away from our old home. Everything was organized and so calm. It was quiet. The cloudless sky, the green grass, the mountains on the horizon, the warm weather. "This is America," I told myself. In Greeley, I joined a nearby high school where I went on to earn my high school diploma. As a college student at one of the public universities in Colorado, I am now studying political science and legal studies and I hope to practice law one day.

In my spare time, I work as a Community Navigator for an immigrant rights organization, helping refugees from East Africa find a home, earn a living, and petition for their families to join them here. I work like my mother worked: so that others' hopes can become real. I work so that other little boys will not be away from their mother for so long. God willing, I will make that difference for families in the same way that difference was made for my mother. 


\section{The Many Faces of Hope: \\ Our Children, Our Future ${ }^{1}$}

Our new home in Greeley, Colorado is simple. Of course, we are far from the rest of our remaining family members (those who are still alive) but it is certainly much safer than anywhere we have sought refuge; be it in Cox's Bazar in Bangladesh, or even in Pulau Pinang in Malaysia.

It was another normal day-I was driving my wife to her English lesson at the refugee center. The sun was shining quite brightly for $10 \mathrm{am}$, so much so that I almost missed the red light. I applied the brakes...a little harder than I normally would.

"Abang, ${ }^{2}$ hati-hati! [Dear, be careful]" said my wife. I nodded.

The kids were at home. It was the beginning of their summer holidays. I was happy for them. Relieved for them.

When the light turned green, I hit the gas pedal, exerting force on my right shoulder as we made the turn. I cried out in pain.

I managed to get off from work for 4 weeks-a severe shoulder sprain, the doctor said. I work at the meat-packers nearby; it is hard manual labor, but it is the only thing I can get.

We finally pulled in to the refugee center. I drove into a parking slot right near the entrancethe parking lot was big. I stopped the car, switched off the engine and turned to my wife who was about to get off.

"Awak datang balik ke, awak tunggu saya? [Will you come and get me? Or will you wait in the parking lot?]" she asked.

"Saya datang balik. See you agak-agak satu jam, [I will come back for you. See you in an hour or so,]" I replied, and smiled at her.

My wife is a very strong woman. She gave birth to our first son on the boat to Malaysia. We were very lucky that there were no complications; lucky to have made it; lucky to still be alive. From Bangladesh, we had managed to catch a boat to Malaysia. We made a short stop-over somewhere in Thailand. I remember some people had to get off from our boat-I remember their scared faces. We stayed on and the boat sailed to Malaysia. I still remember the waves; they were really strong. It felt like we were on a swing, being rocked back and forth-only that it was not gentle. I don't know how many days had passed, but I recall us finally reaching Malaysia.

A bead of sweat trickled down my left temple. It is warm, I thought. I looked at my watch10.10 a.m. - What was it that he asked me yesterday? I thought hard, trying to remember what yesterday's conversation was about with our friend.

\footnotetext{
${ }^{1}$ The Rohingya couple left Bangladesh and lived in Malaysia for more than five years in the informal sector where they had to assimilate with the locals to avoid arbitrary detention.

2 "Abang" in Malay means brother but is used as a term of endearment as well, used by wives to address their husbands. In this case, the word means "dear" or "darling" — it is rare for Malay couples to call each other by their first name.
} 
Ah yes! He asked if I didn't want to find a better job... Our friend, Amir came from a different life-but he has compassion. He understands.

I told Amir about my shoulder sprain and the hard work at the factory.

"That must really hurt!"

"Yes, it does. It started with my lower back. Then, my neck. And finally my shoulder-it feels... stuck."

"I'm so sorry to hear that. Why don't you try to find another job? A better one?"

"It's OK. It's part of life. I have suffered more. A new or better job?... Not so simple. My English is not good. Plus, I have very limited skills."

"But you can attend some skills-building classes...?"

“These classes take time. In the meantime, we need to survive too. It's ok. I will push on-for the sake of my kids. You know, Amir, life is not so simple. For me, my life is over. But this is the time for my children. We are lucky to have resettled here, in the US. My boys speak very good English. They are in school. They learn English here....and other important subjects too. Plus, they now have a better chance than me. So, let them take this chance."

"I understand. Although, you must be able to support them. With this job...are you?"

“It's not an easy job. But I will be strong. My life is over. I don't need a high-paying job for myself. As long as we have enough for food and a roof above our heads, this is enough. It is their turn to shine. This is my hope for them. They also know they are very lucky to be alive, to be here."

I took a deep breath, closed my eyes and held back the tears. Despite that, a tear spilled from my right eye and rolled down my cheek. 'Yes,' I thought, 'my life is over...and my children's have finally begun.' When I opened my eyes, I saw my wife coming out of the refugee center.

As she walked towards the car, she waved and called out, "Eh, Abang, kata nak balik ke rumah dulu? [Hi dear, I thought you said you were going home first?]."

I smiled at her as she came closer, and said, "Takdelah, saya lagi menikmati matahari. Syukur sangat kami disini [No, I was enjoying the sun. I feel extremely blessed that we are here]."

As my wife entered the car and slid into her seat, she looked at me intently and gently replied, "Anak-anak kita-ini saat mereka. Waktu kita sudah habis; tapi, mereka...ada peluang! [Our children-this is their time. Our time is over; but they...they have a chance!]" 


\section{The Many Faces of Hope: \\ Home Away from Home}

My hometown, Uvira, was nothing special. It was a small town, maybe small enough to be a village, but it was a beautiful village, nestled between mountains and Lake Tanganyika. Burundi was on the other side of the lake, just ten miles over the water, and Rwanda was just a little north of our village along the main road. Every morning, I heard people start their day early in the morning when it was still dark. I remember the sound of ba mamans (the village women) going to the mountain where they farmed Miyogo (cassava roots) and Miyindi (corn). Sometimes my mom would go, and she would bring vegetables home to us. I never went to the mountain because I heard it was far; moms would say that it's not good for kids to make the journey alone, and that they must go in groups to stay safe. Luckily for me, my mom preferred ma vieties (selling clothes) in the maendeleo (market) near the lake. On their way to the lake, other vendors would pass by and sell different merchandise to us in the village. It was nice because they gave tasters for free, and I would always taste saucissons (sausages).

I loved playing with dirt, making a mess of everything. I loved running around free and innocent-we all did, that is, all the kids around my age. Every afternoon, after lunch and nap time, those who lived near me went out to play with each other. At five years old, I was too young to start school with the big kids, and too big to be with maman all the time. I was right in the middle, free.

One afternoon, my sister and I were playing at another's house when my brother showed up unexpectedly. He was scared and out of breath. He wore an expression I had never seen on anyone before. Without giving an explanation, he told my sister and me we had to leave. We did as we were told and grabbed what we had brought with us and took off after him, running our fastest to keep up. Were we going home?

There was no time for questions, but I knew something had happened. I knew things were different that day.

In fact, the whole week felt different when I thought about it. I remembered my papa spending most days listening to the tiny radio with intense focus, hanging onto every word of the news reports coming in. Usually, when he'd be listening to the radio, one or more of the neighbors would sit next to him and join in. That week, more people were gathered around the radio. All of them seemed worried about something I didn't understand. I remembered my papa listening so closely as if he was expecting the radio to give him permission to do something. He tapped his fingers on it every time he didn't hear something correctly, moving around in the yard for a better signal. My maman spent more time in church that week too. She used to take me, but ever since giving birth to a baby, she would take her instead. Being five, I didn't mind it at all.

This afternoon felt strange; my mom had gone away to church, my dad worked at night so he had left for work, and it was just my brother, sister, and me left alone. The neighbors were all packing, everyone was running around, moms were calling for their kids, grownups were walking a bit faster than normal. It seemed like the entire world was spinning more quickly than usual around me. My brother told me and my sister to get in the house and wait for maman and everyone else to come home, so we could flee together. Then he went back into the streets.

But we could not wait at home forever. We waited as long as we could before my older brother came back into the house, barely breathing, pushing us to move once again. He threw me on his back, with my sister and brother running after us as we left our house into the streets. That was the last time I saw my home for a very long time. 
As we ran down the one main road in town, people were running in every direction. My brother said it was important not to fall down, that's why he had to carry me. He kept saying how we needed to be out of Uvira before they came back for him. Some people were running toward Burundi like us, some were running toward Baraka-no one knew where safety was going to be found. Men with big guns were walking in the main street and we were all doing everything we could to not upset them, not make eye contact and not even get noticed. Some men with big guns were wearing uniforms while others weren't; it was impossible to tell who was who or what those men were there for. Sometimes they'd call on other boys in the middle of the street, tear them from their families to carry their luggage and their guns.

Sonidda, my older brother, said they would recognize him if they saw him; they had taken him once before. We had to plan a new route, away from the main road. We headed to the outskirts of town, toward the lake for cover. Walking down next to the lake, people were still running in different directions, but there were no men with guns. We walked a bit slower as my brother had put me down so that I could walk alone. My sister helped a family carry their baby girl, and my other brother carried our bags.

We walked for three days.

We lived in Rwanda for a long time. I even started school there. Every so often, my brother made us all get dressed in our best clothes to go meet the people at the UN office. The appointments were non-negotiable: whenever you had an appointment, you had to show up on time or risk losing your case. The office was far from us; we took three buses to get there when we could, but often we had no choice but to walk. It was nice to walk there sometimes because we could see where the president of Rwanda lived, there in Kigali. There were always men with big guns around that building, and no one walked in this area; everyone was in their cars, everyone looked happy, like they had arrived at their final destination. I had never felt that. We had lived in Kigali as if we would have to move at any given time, while the people there looked relaxed; they looked like they had unpacked for good. I always wondered if the men with guns did not scare them. I never understood this. I was always waiting to go back home, to see maman and papa again, to play in the dirt with my friends.

It was always a muzungu (white man) asking us questions at the UN office. They were the same questions every time; I even memorized the answers. My brother said it was rude to answer questions unless I was asked directly, but the man always asked the same questions and I always gave the same answers. He didn't really want to know about my life, the life I had then, the one with my new friends, and my new school and my new church. He wanted to know about the life I wanted but couldn't have. The life where I left my parents, the life where my brother was taken, beaten, and forced to eat meat otherwise they'd kill him; the life where we had to move three different times because strange men were always looking for my brother. The life we are running away from; the life that brings tears to all of us when we speak of it, and he watched us cry.

He talked of a different life, a new life, a life where he promised safety for all of us. Every time we went to the UN office, we were promised this life. It was promised so many times that I started to think he was just saying it to us to give us hope. It worked, I guess; I believed him. He gave us hope-hope that one day we would have a life where I would go to school every day, where I would live in a house like that of the president's neighbors, and drive the cars they drove and eat the food they ate. 
I hoped for this life. I waited for this life. We waited for ten years for this life, getting by on just the hope that these muzungus fed to us with each visit. But then it actually happened and hope became my reality.

I have been living in the United States for ten years now and I have been naturalized as a citizen. When I first arrived, it was difficult to see this new place as my home. I was separated from my siblings again and was put into foster care. It seemed like everyone was interested in knowing where I was from, where home was for me. People would ask, and to me, home was still Uvira. Home was still the memory of playing with my friends in the dirt, with adults from the village watching over us, talking, teasing each other. I did not know how to explain that to these Americans I was meeting who had no knowledge of the Congo. It was difficult, too, coming to a country that spoke English when I couldn't speak any back.

Foster care looks different for everyone, but for me, meeting my new family was the best thing that could happen. My foster family showed me a love I hadn't felt since I was a child: they loved me unconditionally, and continue to do so.

My foster father is a funny man; he taught me everything I know today. He even taught me how and why it's important to fill up gas to exactly $\$ 10$. He'd be very concerned if I didn't get it right. I know now, of course, that putting gas in the car is not that stressful. He taught me how to be successful in this new life, things I needed to know and things I needed to know just in case. My dad helped me understand a world outside my own, a world where I could be anyone I wanted to be; where the only one who was allowed to have expectations of myself was myself. He showed me a world where he and the rest of the family would always be there for mewhere nothing would ever separate us.

Thanks to my foster family and the community I have built over the years, I am making my own path for myself, taking risks and following my own hopes and dreams. Today, I am pursuing a master's degree in human rights law. I am studying to make this world a better place, a safer place, a place where the dreams of little girls in the Congo become real.

I am at peace now; I know where home is. This new life of mine, this new family that is here for me for the rest of my life. I know they're not going anywhere. 